\title{
ANTHROPOGENIC AND NATURAL DYNAMICS OF LANDSCAPE ECOSYSTEMS OF THE SLOVECHANSKO- OVRUCHSKY RIDGE (UKRAINE)
}

\section{Oleksandr Harbar, Ivan Khomiak, Iryna Kotsiuba, Nataliia Demchuk and Iryna} Onyshchuk

\author{
Department of Ecology and Geography \\ Faculty of Natural Sciences \\ Zhytomyr Ivan Franko State University \\ V. Berdychivska Str. 40, 10 008, Zhytomyr, Ukraine \\ e-mail: o.v.harbar@gmail.com
}

\begin{abstract}
The need for landscape management cannot be satisfied by static data alone. Landscape ecosystems are complex dynamic objects and the successful protection or operation of such areas depends on the quality of monitoring their dynamics and the forecasts built on its basis. Forecasting accuracy also depends on the quality of the modelling and this is why it is necessary to highlight the most universal and key characteristics of ecosystems. The Slovechansko-Ovruchsky ridge, which has a phenomenally high variety of landscapes, is well suited as an object for testing approaches to modelling. The authors singled out 11 territorial parts of the Slovechansko-Ovruchsky ridge at the level of landscapes and tracts. The differentiation of these landscapes was assessed using the symphytoindication method to determine the value of natural and anthropogenic dynamics. This made it possible to build prognostic algorithms for ecosystem changes using geobotanical data and produce prospects to create the best suitable landscape protection strategy or more effective and safe exploitation of landscapes.
\end{abstract}

Keywords: habitats, autogenic successions, allogeneic successions, environmental monitoring, human impact

\section{INTRODUCTION}

Modern natural resource management requires perfect and large-scale monitoring of ecosystems. At the same time, the requirements for monitoring are its consistency, regularity and forecasting regarding the future of the objects under study (Didukh, 2008). Fulfillment of these requirements is impossible without characterizing the dynamic processes that occur in ecosystems (Margalef, 1994). This is primarily in regards to natural and anthropogenic dynamics (Khomiak et al., 2019).

There are two fundamentally different types of dynamics: allogeneic and autogeneic successions. Autogenic successions are the process of self-organization of ecosystems without external interference. This is natural dynamics. Allogeneic successions require external influence. This is anthropogenic dynamics if the allogeneic succession is caused by human activity. In most of the cases, the anthropogenic and natural dynamics values 
are inversely proportional and have opposite vectors of influence on changes in the ecosystem. Exceptions to this are the planting of aboriginal tree species and eutrophication of poor soils. Often, anthropogenic impacts hinder the self-restoration of natural landscapes and therefore require constant monitoring to manage natural resources. Landscape-level ecosystems are complexes in which living organisms are specifically united with an abiotic environment on a conditionally homogeneous area of the earth's surface. These connections make it possible to identify some elements of the system according to the characteristics of others (Cordingley et al., 2016). According to the Monocentric Ecosystem Model, vegetation is the best indicator of environmental characteristics (Didukh, 2005). This allows us to assume that the territorial differentiation of landscapes at the level of geobotanical tracts will be sufficient to distinguish landscapes with different levels of natural and anthropogenic dynamics (Sochava, 1968).

The Slovechansko-Ovruchsky ridge was selected as a model region for study as it possesses a high variety of landscape ecosystems, in stark contrast to its surroundings (Khomiak, 2006). Various geological, geomorphological and pedological features and anthropogenic influences, which are at different dynamic stages of development, can be observed here on a relatively small area of landscape ecosystems (Didukh and Khomiak, 2007). Since the beginning of the twentieth century and until now, it has attracted the attention of researchers from various fields including geologists, biologists, ethnographers, linguists, historians, geographers and archaeologists (Melnyk et al., 2009; Tutkovsky, 1923; Koshik et al., 1976). Thus far a project has been launched to create an international Ukrainian-Belarusian biosphere reserve "Prypiat Polissia" with the participation of its territory and this has increased the requirements for monitoring the territory and predicting the consequences of changing human activities (Simeonova et al., 2009). According to Viktor Sochava regarding the structural-dynamic principle of landscape analysis, it is impossible to obtain a reliable forecast without the use of a cartographic method (Sochava, 1967).

The processes of anthropogenic transformation should be the central object of environmental monitoring in this area. This region has complex socio-economic problems and the cause of these is the distance from industrial centers and a poorly-developed transport infrastructure. Local communities must be guided by the principles of sustainable development to stop their social and economic degradation. As this area has a large number of natural landscapes that attract tourists, a combination of recreation and landscape-scale conservation can be an effective and promising way of business in this area. Local communities can overcome socio-economic difficulties if they control the level of anthropogenic transformation of ecosystems.

\section{MATERIALS AND METHODS}

The Slovechansko-Ovruchsky ridge is located in the northern part of the Zhytomyr region with a total area of $434 \mathrm{~km}^{2}$. The surface of the ridge rises from $200 \mathrm{~m}$ to $319 \mathrm{~m}$ above sea level. The geomorphological basis of the ridge is the Ovruch graben and all geological 
rocks belong to the Ovruch volcano-sedimentary sequence. The ridge soils (in the western part of the territory) are mainly sod-podzolic and gray forest soils. There are many small wetlands and powerful groundwater. The climate is of a warm-summer humid continental type, and natural vegetation is well preserved. The largest areas are occupied by forests $\left(217.94 \mathrm{~km}^{2}\right)$ while the rest of the plant communities are meadow $\left(32.96 \mathrm{~km}^{2}\right)$, swamp $\left(9.0 \mathrm{~km}^{2}\right)$, agroecosystems $\left(156.94 \mathrm{~km}^{2}\right)$, urban $\left(\right.$ about $\left.8.2 \mathrm{~km}^{2}\right)$, water $\left(3.5 \mathrm{~km}^{2}\right)$, and shrub $\left(5.0 \mathrm{~km}^{2}\right)$ types. As of 2019 , there are 1,282 species of higher vascular plants that are known. A difficult economic and social situation exists on the territory of the northern border of Ukraine and this also applies to the Slovechansko-Ovruchsky ridge. Many agricultural lands are not in use at this time. The local population works in the forest industry or in the subsistence economy and seasonal collection of wild mushrooms and berries.

Standard geobotanical field methods were used in this research (Myrkyn et al., 2001) and carried out by route-expeditionary and stationary methods in the period from 2004 to 2006. A series of 835 standard geobotanical descriptions and six ecological profiles were created. The parameters of the environmental factors were determined by the synphytoindication method (Didukh, 2012) using Simargl 1.12 software (Khomiak et al., 2018). The values of abiotic factors (soil humidity, variability of damping, acidity, salt content, nitrogen content, carbonate content, soil aeration, light degree in cenoses, climate thermic mode, humidity, continentality, criomode) are given according to the Didukh-Plyuta scale (Didukh and Plyuta, 1994); the anthropogenic factors are according to the Didukh-Khomiak scale (Didukh and Khomiak, 2007; Khomiak et al., 2018); and the value index of dynamics is based on the scale developed at the Zhytomyr Ivan Franko State University laboratory of ecosystem theory (Khomiak et al., 2019).

The value of anthropogenic transformation is established by the level of anthropotolerance (hemeroby index) and projective cover for a species of plants. The classes of hemeroby according to Hans-Peter Blume and Herbert Sukopp (1976) were divided into an 18-point scale: ahemerobic (1-3 points), oligohemerobic (4-6 points), mesohemerobic (7-9 points), euhemerobic (10-12 points), polyhemerobic (13-15 points), metahemerobic (16-18 points). All levels of the organization of life which are above the level of the organism have such a characteristic as anthropotolerance. It is possible to use the term hemerobic for populations, species, communities and ecosystems, e.g., an ahemerobic ecosystem, an oligohemerobic ecosystem and so on. The following formula was used to determine the magnitude of anthropogenic transformation of a particular ecosystem:

$$
H E=\frac{k_{1} H e_{1}+k_{2} H e_{2}+\ldots+k_{n} H e_{n}}{k_{1}+k_{2} \cdots+k_{n}}
$$

where $\mathrm{HE}$ is the value of anthropogenic transformation of the ecosystem; $\mathrm{He}_{1}, \mathrm{He}_{2}$, $\mathrm{He}_{\mathrm{n}}$ is the middle of the amplitude of anthropotolerance of species; $\mathrm{n}$ is the number of informative species in the description; $\mathrm{k}_{1}, \mathrm{k}_{2}, \mathrm{k}_{\mathrm{n}}$ is the projective coverage of the species in points according to the new Braun-Blanquet system. 
The dynamics index is set by the amount of above-ground phytomas and its age. A 21-point scale of natural dynamics was developed through observations of changes in above-ground phytomas and its age during autogenic successions. The presence of species in ecosystems with different values of the natural dynamics index was determined (Khomiak et al., 2019). A database of species tolerance amplitude relative to the value of the dynamics index was created. Standard geobotanical descriptions can be used to determine the index of natural ecosystem dynamics by the formula:

$$
S T=\frac{k_{1} S_{t 1}+k_{2} S_{t 2} \cdots+k_{n} S_{t n}}{k_{1}+k_{2} \cdots+k_{n}}
$$

where $\mathrm{ST}$ is the index of natural dynamics; $\mathrm{k}_{1}, \mathrm{k}_{2}, \mathrm{k}_{\mathrm{n}}$ is projective coverage of the species № 1, 2, $\mathrm{n}$ in points according to the new Braun-Blanquet system; $\mathrm{St}_{1}, \mathrm{St}_{2}, \mathrm{St}_{\mathrm{n}}$ is the middle of the tolerance range to the value of the dynamics of the species № $1,2, \mathrm{n}$. Classification of the vegetation was made based on the Braun-Blanquet methodology of ecological-floristic criteria according to the prodromus of the vegetation of Ukraine (Khomiak et al., 2020).

\section{RESULTS}

The authors identified relatively homogeneous areas in terms of anthropogenic transformation. The territory was differentiated into such categories by means of a ratio of the areas of sites with certain sizes of anthropogenic transformation:

- oligohemerobic, including ahemerobic ecosystems;

- mainly (more than $75 \%$ of the area) oligohemerobic ecosystems;

- oligohemerobic and mesohemerobic ecosystems;

- euhemerobic and mesohemerobic ecosystems;

- euhemerobic and polyhemerobic ecosystems.

GPS coordinates of geobotanical descriptions and a visual analysis of satellite images of the study area were used to create the map. A cartographic analysis allowed for dividing of the ridge into two well-defined areas (Figure 1). The western part of the ridge and the northern protrusions are represented mainly by oligohemerobic ecosystems. The central part and the eastern and south-eastern outskirts of the ridge are euhemerobic and mesohemerobic ecosystems. This part of the ridge is highly mosaic and has no ahemerobic ecosystem. The western territory and the northern protrusions of the ridge are more homogeneous.

The location of ecosystems with different values of the natural dynamics index is caused by other patterns than for their anthropogenic transformation (Figure 2). Ahemerobic ecosystems do not always have high values of the natural dynamics index. These are mainly mesotrophic and oligotrophic wetlands located at a distance from settlements. They are located in the river valleys of the western part of the ridge. Large oligohemerobic forests 


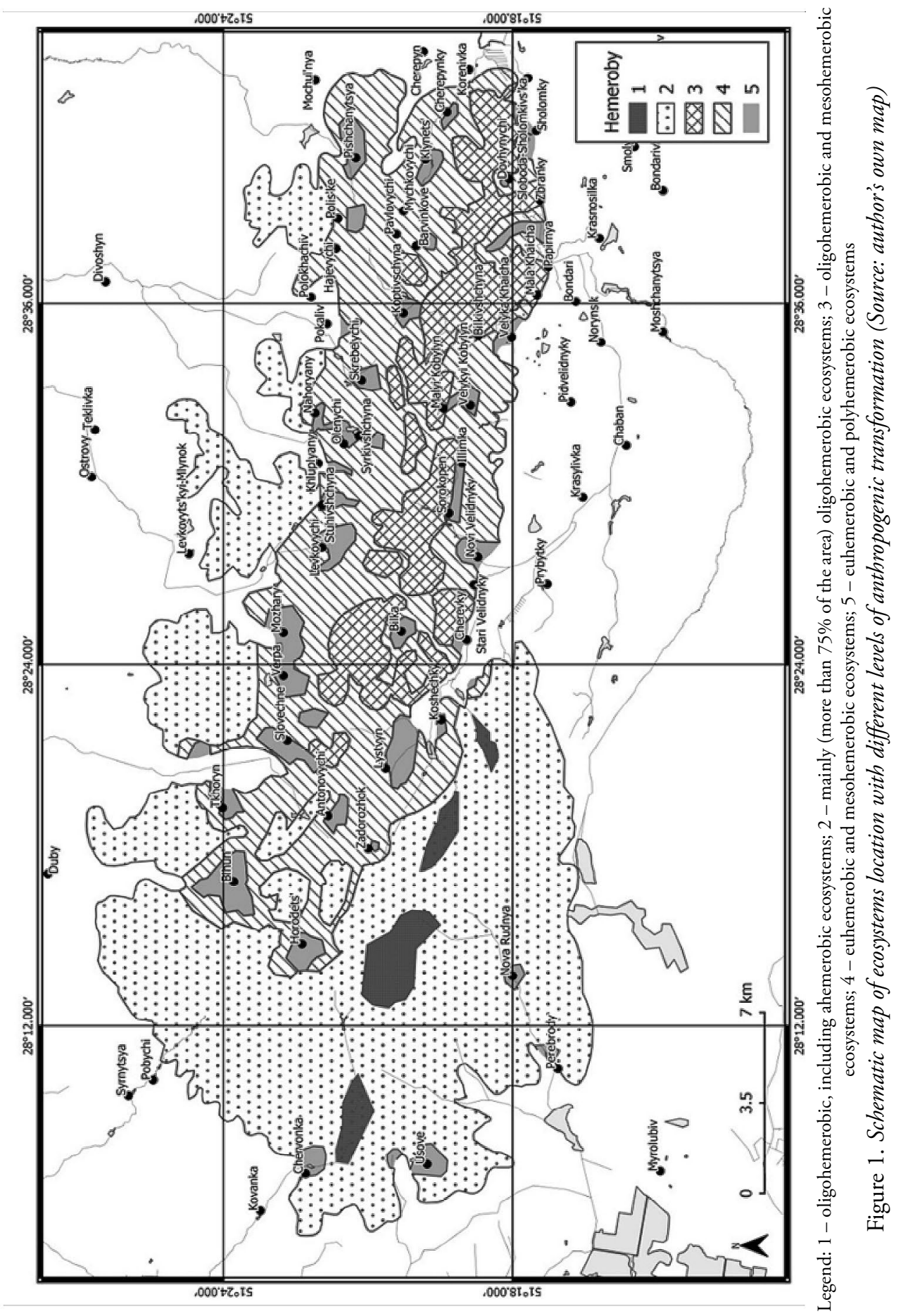




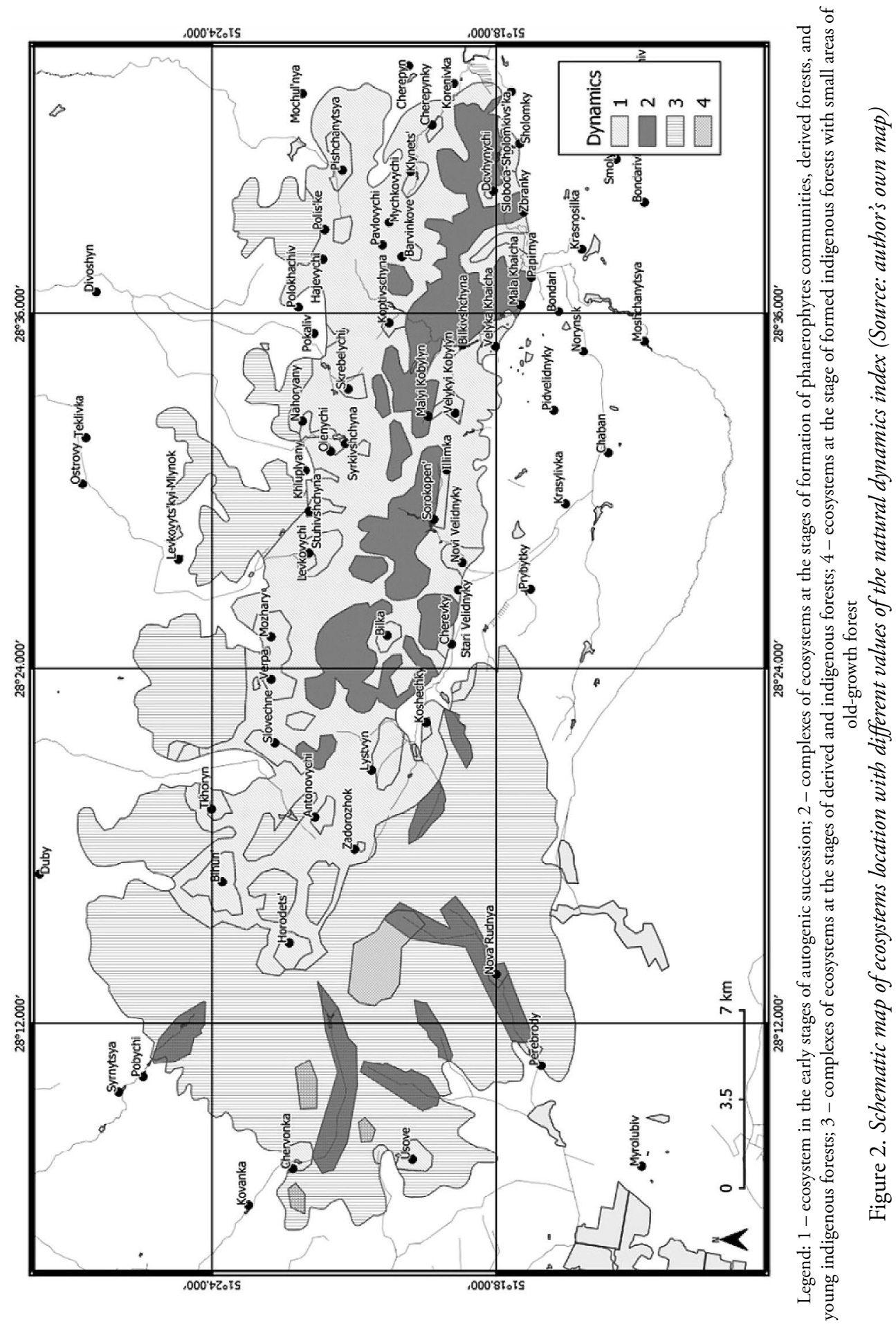


have average values of the dynamics index. This can be explained by the lack of significant areas of old natural forests in this area. Western ravine forests, despite the lower anthropogenic pressure, do not acquire the maximum values of the dynamics due to active erosion processes. The data was generalized to build a map-scheme (Figure 2) and distribution was carried out taking into account the ratio of areas of individual groups of ecosystems:

- Territories with ecosystems at the initial stage of succession (1-4 points of the natural dynamics index);

- Territories with a complex of ecosystems at the stage of transition from grasslands to phanerophyte communities (5-8 points of the natural dynamics index) and at the stage of derived or young indigenous forests (9-12 points of the natural dynamics index);

- Territories with a complex of ecosystems at the stages of derived and indigenous forests;

- Ecosystems of formed indigenous forests (13-16 points of the natural dynamics index) with small areas of virgin forests (more than 16 points).

Ecosystems approaching the climatic climax of autogenous succession (17-21 points of the natural dynamics index) are very rare and located in small areas.

An ecological $45 \mathrm{~km}$ long profile was laid along the $51^{\circ} 20^{\prime} \mathrm{N}$ parallel (Figure 3). The western part of the ridge has smaller fluctuations in the values of the index than the eastern part. The increase in altitude from $200 \mathrm{~m}$ to $300 \mathrm{~m}$ in the west and the features of the relief have little effect on the changes of anthropogenic transformation here. The only exceptions are rivers and their coastal zone. This profile did not cross the rivers and swamps of the western part of the territory, so the effect on the decrease in the value of the dynamics index remained unnoticed here. On the eastern part of the ridge, however, the value of the dynamics index is relatively higher in the river valleys. Soils and sediment rocks of the eastern part of the territory are affected by water erosion. There are many ravines occupied by forest vegetation. Depending on the water erosion activity and the characteristics of the rocks exposed by it, a high mosaic of microlandscapes is formed here.

The main factors in the formation of landscape ecosystems are soils and underlying sedimentary rocks, soil humidity associated with microrelief, characteristics of human activity, and the stage of autogenic succession. These characteristics allow the territory to be divided into separate landscape ecosystems. Their boundaries coincide with the boundaries of areas identified by geobotanical methods.

According to geobotanical zoning, the territory of the ridge belongs to the KorostenZhytomyr district of the physical-geographical region of Zhytomyr (Central) Polissia (Andrienko et al., 1977). The territory of the ridge is divided into two regions: the Chervonsko-Horodetsky region with acidophilic sessile oak forests, and the Ovruch region with oak-hornbeam forests that fully correlate with the traditional division of the ridge into loess and rocky (quartzite) areas (Figure 4) (Yakushenko, 2005). They differ in their complex of geological, soil, cenotic, anthropological characteristics and microrelief. 


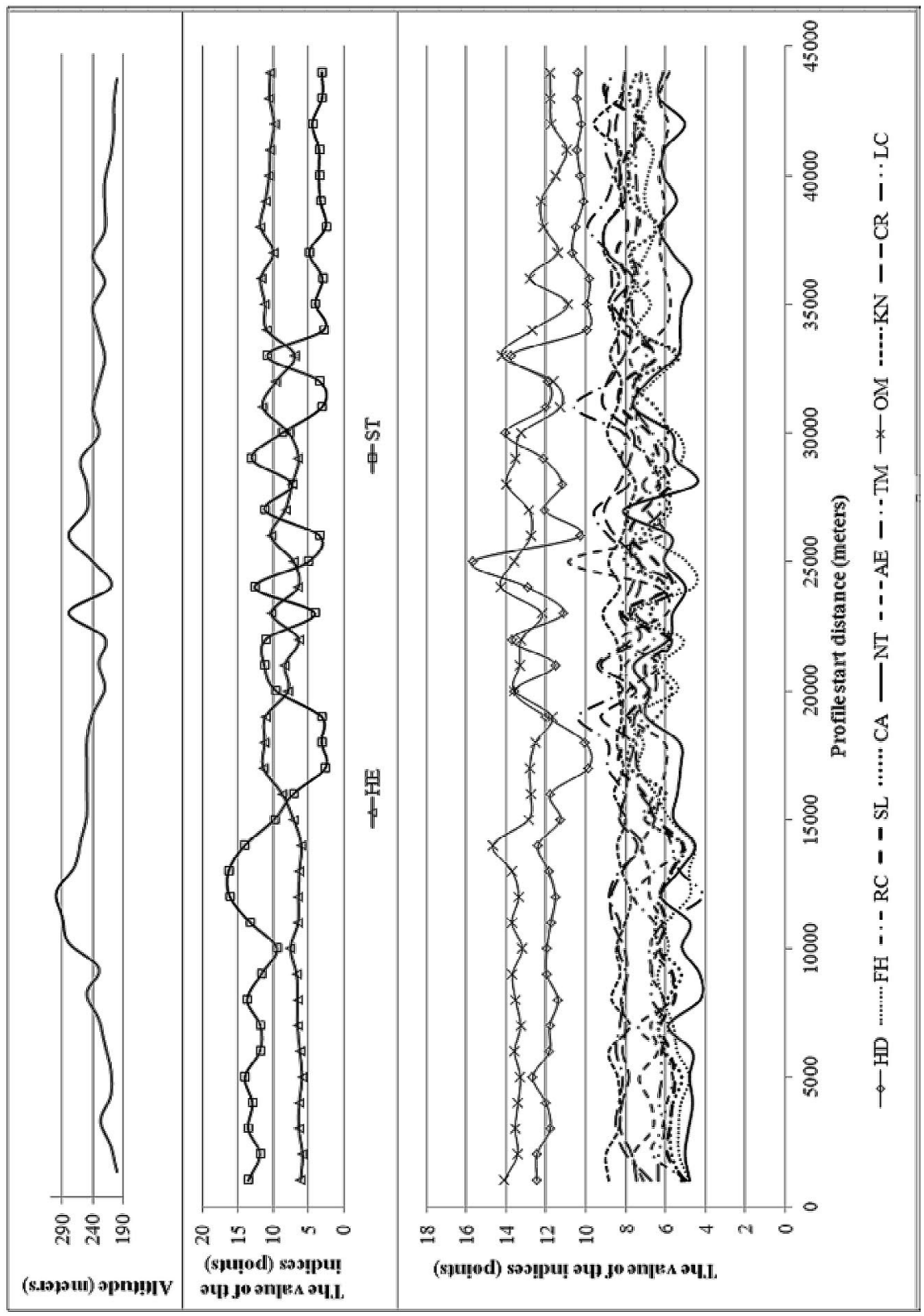

俤

究产要

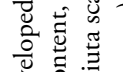

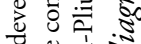

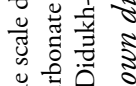

氙记

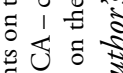

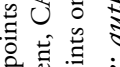

苞

उ. 8 :

范

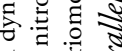

तु 1 है

艺全之

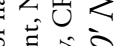

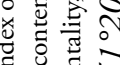

㱐

的 1 苛ई

के

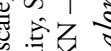

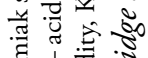

है 1 . ․ㅗ

है है

㐘

词泀

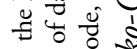

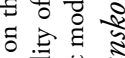

药 卷

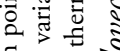

$\Xi 1$ क

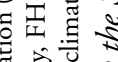

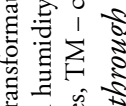



षํำ

먼 च

氞荡

苍专

$\cong \because$

जे 1 i



च्च

㟧 
Within the framework of the first region, poor and mainly medium-stony sod-podzolic soils are widespread. The topography is hummock-and-hollow with hills up to $319 \mathrm{~m}$ above sea level. Human activity is mainly represented by forestry. Field cultivation is concentrated within a few small settlements. In the last several decades, the population has decreased sharply and most of the arable land lays fallow.

Within the second region, agricultural land prevails on the light gray forest soils above the loess sedimentary rocks. Human activity on the slopes of the loess hills has led to active gullying (Khomiak, 2015). Forest ecosystems have been formed in the gullies. In the west, they are predominantly of a natural type, while in the east, through the influence of plantings of invasive transformer species, they are synanthropic derivatives (Khomiak, 2006). There are four tracts within the Chervonsko-Horodetsky district of acidophilous sessile oak forests. They are similar in many environmental factors and vegetation types. These landscapes differ in relief, the presence of mineral fragments in the soil, and the distribution of areas with different values of indices of natural and anthropogenic dynamics.

The Tkhorinsko-Pishchanytske tract is acidophilic pine-oak forests. Located in the north of the ridge, it consists of five rocky hills occupied by transformed forest lands, divided by the Slovechna, Yasenets, Zvonka, and Polokhachevka rivers. There is a difference in height from $180 \mathrm{~m}$ above sea level in river valleys and up to $260 \mathrm{~m}$ on individual peaks. The heights of the tops of individual rock massifs decrease from west to east from $260 \mathrm{~m}$ to $220 \mathrm{~m}$. The length of the massifs is approximately $3-5 \mathrm{~km}$ from north to south and $2-3 \mathrm{~km}$ from west to east. Permanent rivers and streams are not common because the massifs have small areas. There are sod-podzolic soils, which have small fragments of quartzite and pyrophyllite. The landscape ecosystems are mainly oligohemerobic (4-6 points) and are at the stage of young and late indigenous forests according to the natural dynamics index (9-16 points).

The Bigunsko-Horodetske tract is acidophilic pine-oak-rhododendron forests. It is located northwest of the Bigun-Horodets line and occupied by transformed forest lands and relict groups of Hedera helix L. The landscape consists of two massifs between the Bigun and Pertnitsa rivers separated by the valley of the Zymukha River. The maximum heights of these massifs are $260 \mathrm{~m}$ and $253 \mathrm{~m}$. Sod-podzolic soils are medium stony. Quartzite fragments with a diameter of about $10-20 \mathrm{~cm}$ in the soil are found closer to the tops of the massifs. The ecosystems are mainly oligohemerobic and the value of the natural dynamics index is 9-16 points. In the Zymukha River valley there are mainly mesohemerobic ecosystems and the value of the natural dynamics index is 5-8 points.

The Chervonsko-Horodetske tract has typical acidophilic sessile oak forests and is located in the Horodets - Chervonka - Usovo triangle. It is occupied by transformed and natural forests and wetlands. This tract is located between the Pertnytsia River and the left tributary of the Lubenets River. It consists of two hills $(285 \mathrm{~m}$ and $321 \mathrm{~m})$ separated by the valley of the Chervonka River. Sod-podzolic soils are very stony. Large blocks of quartzite $(0.2 \mathrm{~m}$ to $1 \mathrm{~m}$ in diameter) appear on the day surface on some slopes. The largest areas of ahemerobic ecosystems and virgin forests with a natural dynamics index of more than 16 points can be observed here. 






守 吾

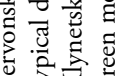

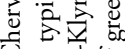

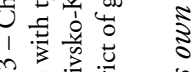

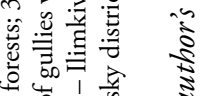

4 눙

훕

०ै

乐过

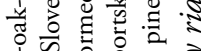

究论

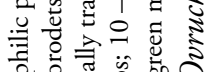

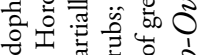

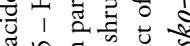

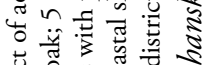

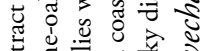



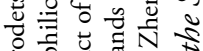

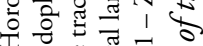



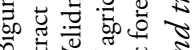

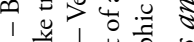

人

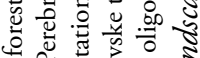

당

药

है है है

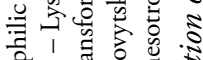

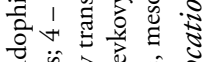

马ु

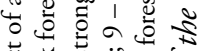

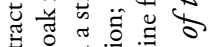

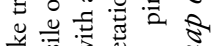

舟苟

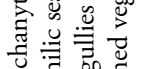

ज़

它芯芯额

. تٓ

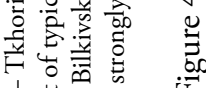

-

$\ddot{\forall} \circlearrowleft$

㟲装量产 
The Lystvynsko-Perebrodske tract is acidophilic pine-oak forests. It is located between the settlements of Perebrody and Lystvyn south of the plateau with a height of $319 \mathrm{~m}$ and heights of $250 \mathrm{~m}$ and $261 \mathrm{~m}$ to the north and is occupied by transformed and natural forest and wetlands. Typical sod-podzolic soils are predominant here. The soils are formed by winnow sands on the periphery of the territory of the ridge. Loams and inclusions of quartzite fragments are found closer to the tops of hills. These landscapes are primarily oligohemerobic but have lower values of the natural dynamics index (up to 14 points). The Ovruch region of oak and hornbeam forests can be divided into five tracts. The area is divided into smaller landscape ecosystems by the level of anthropogenic transformation of ravine forest. There is a change in the origin of vegetation which is completely natural in the west and mostly introduced in the east.

The Horodetsko-Slovechanske tract is gullies with typical deciduous forests. It includes the western part of the solid woods to the Verpa-Cherevky line. This landscape ecosystem has the highest hills of this part of the ridge - up to $316 \mathrm{~m}$. It borders with the Chervonsko-Horodetsky district of acidophilic sessile oak forests. The soils are gray forest loam on a loess basis. The ravine forests are well preserved in their natural state. Gully outskirts are exposed to higher anthropogenic pressure. They are restored derivative forests, shrubs or forest-edge ecosystems. There is a great contrast in the index values of anthropogenic transformation between the gully outskirts and the bottom and slopes of the ravine.

The Bilkivske tract is gullies with strongly transformed vegetation. It includes areas with gullies of the Bilka River valley. This landscape ecosystem has hills with a lower height (up to $269 \mathrm{~m}$ ), smaller depth and greater width of ravines. The depth of the ravines is not more than $20 \mathrm{~m}$. In the Horodetsko-Slovechanske tract, the width of the ravine system is $100-200 \mathrm{~m}$ on average, and in the Bilkivske ravine system it is $400-500 \mathrm{~m}$. There are exits to the day surface of bog iron ore in the valley of the Bilka River. Landscapes are mainly mesohemerobic and euhemerobic. Euhemeroby is observed only at the bottom of ravines. The value of the natural dynamics index reaches a maximum of 13 points on the upper slopes part of ravines.

The Velidnytske tract is gullies with partially transformed vegetation (includes areas with gullies on the southern slope of the ridge between the valleys of the Bilka River and the Illimka River). This landscape ecosystem has the smallest area. It is represented by the slopes of the Noryn River valley. The right bank of the valley is completely anthropized, and the left bank has fragments of natural vegetation in the ravines. This area is an example of the transition from natural ravine forests of the western part of the territory and artificial plantations of introduced species of the eastern part. There is a high mosaic of sedimentary rocks. It is dominated by loess on top of pink Ovruch quartzites, which sometimes come to the surface in monolithic blocks. Strong layers of clay are observed, and the lower part of the left bank of the Noryn River is formed by coarse-grained sands with numerous marine fauna fossils of the Jurassic period.

The Illimkivsko-Klynetske tract is gullies with strongly transformed vegetation. It includes areas with gullies on the southern slope of the ridge from the valley of the Illimka 
River to the valley of the Klynets River. The depth of the ravines is maximum here and reaches $70 \mathrm{~m}$, despite the low heights of the hills $(250 \mathrm{~m})$. This is due to the difference in the height of the hills and the Noryn valley and its tributaries. The Noryn River flows at an altitude of $152 \mathrm{~m}$, and its left tributaries, at the $180-183 \mathrm{~m}$ and cut into the ridge. The sides of the ravines are completely occupied by man-made plantings. Introduced species have invaded the middle of the ravines and changed the vegetation of the landscapes, displacing aboriginal species and plant communities.

The Levkovytsko-Korenivske tract is agricultural land and coastal shrubs. It is located on the northern slope of the forest part of the ridge and extends east of the valley of the Yasenets River. These ecosystems are occupied on the northern slope of the loess part of the ridge. The heights of the hills reach $282 \mathrm{~m}$ but the ravines are very small. A group of individual hills with a height of $207 \mathrm{~m}$ to $282 \mathrm{~m}$ are located in this part of the ridge. It is a watershed that divides the basins of the Uzh and Pripyat rivers. The system of hills of the Thoryn-Pishchanytsia landscape ecosystem rises further to the north. Most of the erosion formations in this area have the form of synanthropized and inhabited river valleys.

To the south of the village of Cherevky typical pine forests stretch along the southern slope of the ridge. The length of this strip is about $8 \mathrm{~km}$ and the width is about $700 \mathrm{~m}$ (from $300 \mathrm{~m}$ to $2,200 \mathrm{~m}$ ). The vegetation and indicators of environmental factors are different from the rest of the ridge. They are similar to the neighboring Zherevsky region of green moss pine forests, adjacent to the ridge from the southeast. The belonging of this territory to the Chervonsko-Horodetsky region of acidophilic common oak and sessile oak forests is doubtful. A similar situation is observed on the northwestern edge of the ridge. This territory is adjacent to the Ubortsko-Slovechniansky geobotanical region of the Pivnichnopolisky district. Thus, on the territory of the ridge ( $200 \mathrm{~m}$ above sea level with outcrops of Ovruch quartzites), the surroundings of the Ubortsko-Slovechniansky region of green moss-lichen pine forests of, mesotrophic and oligotrophic bogs and Zherevsky district of green moss pine forests.

\section{DISCUSSION}

An analysis of the correlation between indicators of natural and anthropogenic dynamics showed a typical diagram for similar studies finding an inverse linear relationship between them (Figure 5). The Pearson correlation coefficient of this relationship is 0.6. This pattern demonstrates that human activity often slows down the processes that accompany autogenic succession. Namely, an increase in anthropogenic impact, as a rule, leads to a decrease in indicators of natural dynamics. In this case, the indicator of the dynamics was determined by the value of the above-ground phytomass and its age, which corresponds to the changes along with the autogenous succession.

Therefore, the increase in anthropogenic pressure shifts the landscape ecosystem towards the pioneer stages of succession, and its decrease shifts the landscape ecosystem towards the climax. Each of the landscape ecosystems at the tract level is differentiated 
not only with the help of original geological, geophysical, or phytocenotic components, but has a different ratio of areas for settling, which, depending on different edaphic and microclimatic conditions, are at different stages of succession and are anthropogenically transformed in different ways.

This is most clearly observed at the level of landscapes of the loess and quartzite parts of the ridge. The loess part mainly consists of agricultural lands and territories of settlements with highly anthropogenically transformed ecosystems. Between them there are gullies covered by natural vegetation (Khomiak, 2014). The bottom and slopes of the gullies practically do not experience direct anthropogenic impact (Khomiak and Onyshchuk, 2018). Sometimes spontaneous illegal felling of trees occurs here, mainly windbreak and dead wood. The widest lower parts of the bottom of the gullies covered with meadow vegetation are used as hayfields and pastures. The sides of the gullies that border on agricultural landscapes are more strongly transformed (Figure 6). This is quite a fairly contrasting mosaic pattern with very different microlandscapes in terms of the level of anthropogenic transformation (Khomiak, 2015).

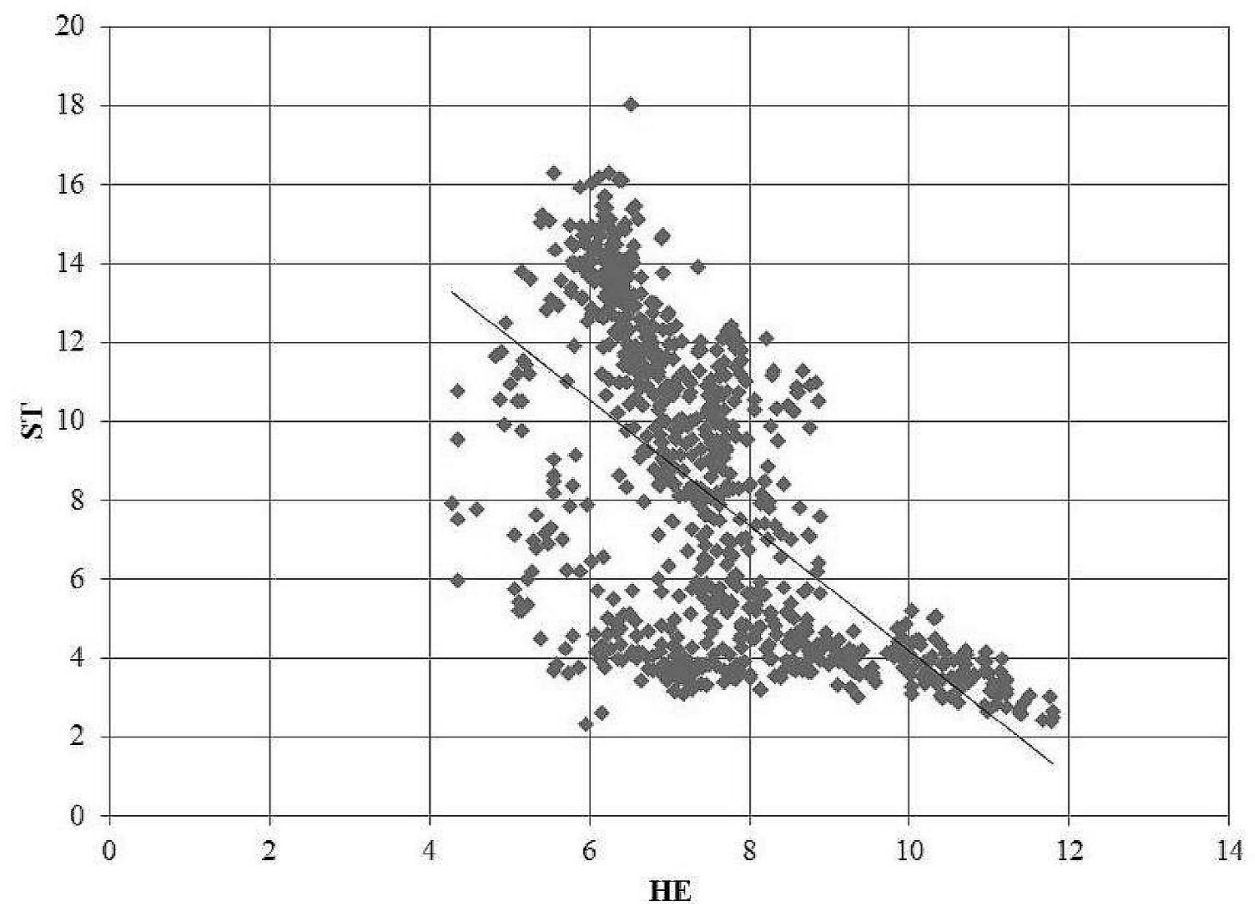

Figure 5. Dependence between indices of anthropogenic transformation and natural dynamics on the territory of the Slovechansko-Ovruchsky ridge (Source: author's own diagram) 


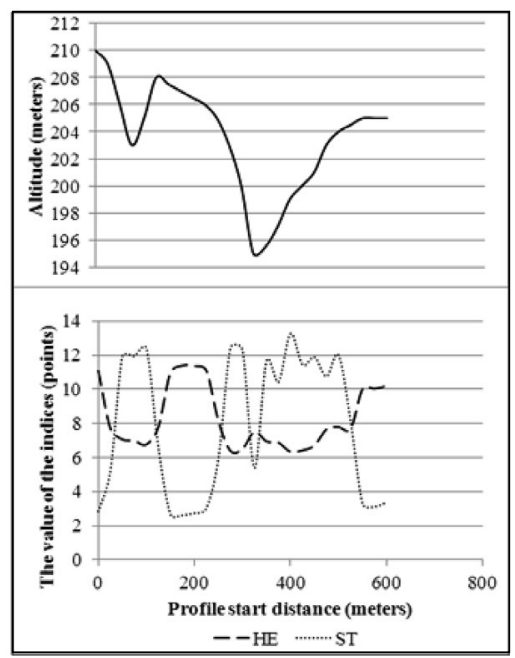

Legend: HE - index of anthropogenic transformation, ST - index of natural dynamics

Figure 6. Change in the value of indices of anthropogenic transformation and natural dynamics on the profile through loess ravines near Stari Velidnyky (Source: author's own diagram)

For settlements, agrolandscapes and territories covered by coastal vegetation in this area, the indicators of dynamics have become in latitudinal and meridional directions. The ecosystems of gullies differ greatly in natural dynamics (Khomiak and Didukh, 2009). There is a series of recessions in the indicator of natural dynamics for the gullies of tracts of this region: Horodetsko-Slovechanske $\rightarrow$ Bilkivske $\rightarrow$ Velidnytske $\rightarrow$ IlimkivskoKlynetske $\rightarrow$ Levkovytsko-Korenivske (Figure 7).

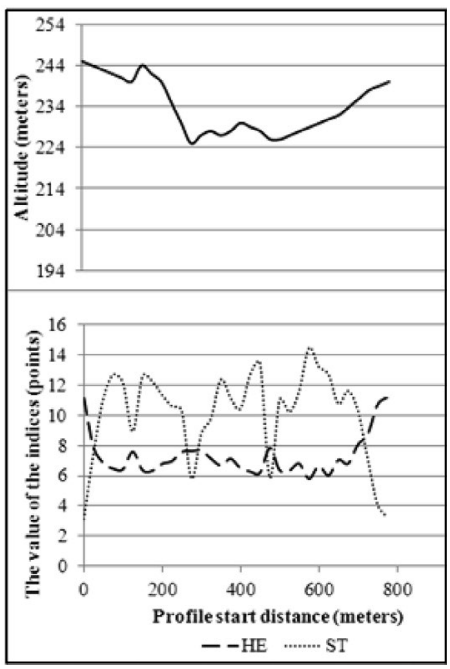

Legend: HE - index of anthropogenic transformation, ST - index of natural dynamics

Figure 7. Change in the value of indices of anthropogenic transformation and natural dynamics on the profile through loess ravines near Bilka (Source: author's own diagram) 
Their differences are not subject to edaphic or orographic characteristics, but due to anthropogenic impact. The only exception is the last tract (Levkovytsko-Korenivske), where, behind relatively gentle slopes, there is an insignificant number of gullies of the required depth and area (Figure 8).

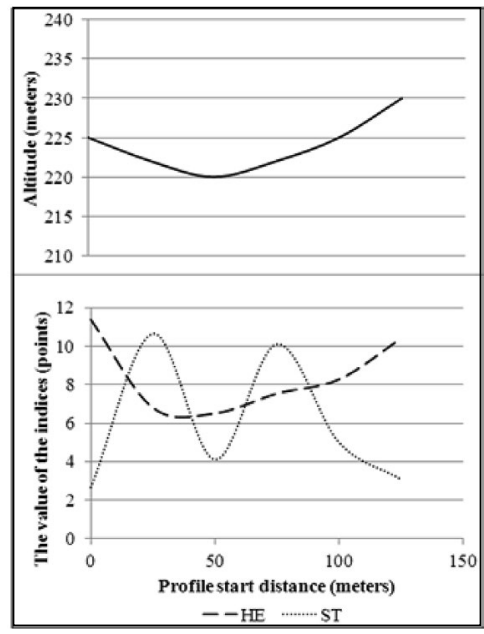

Legend: HE - index of anthropogenic transformation, ST - index of natural dynamics

Figure 8. Change in the value of indices of anthropogenic transformation and natural dynamics on the profile through loess ravines near Syrkivshchyna (Source: author's own diagram)

In the gullies of the Horodetsko-Slovechanske tract there are the maximum values of the indicator of natural dynamics (Figure 9).

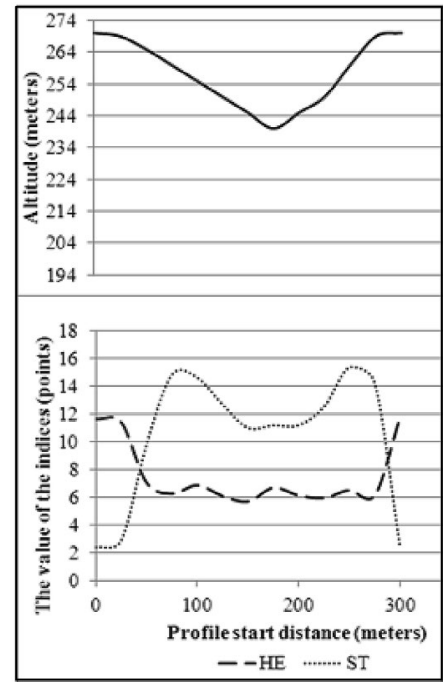

Legend: HE - index of anthropogenic transformation, ST - index of natural dynamics

Figure 9. Change in the value of indices of anthropogenic transformation and natural dynamics on the profile through loess ravines near Horodets (Source: author's own diagram) 
In some cases, the indicators reached 15-18 points. This indicator is 9-12 points on average in the Ilimkivsko-Klynetske tract, and it is decreased to 6-9 points in the Levkovytsko-Korenivske tract (Figure 10).

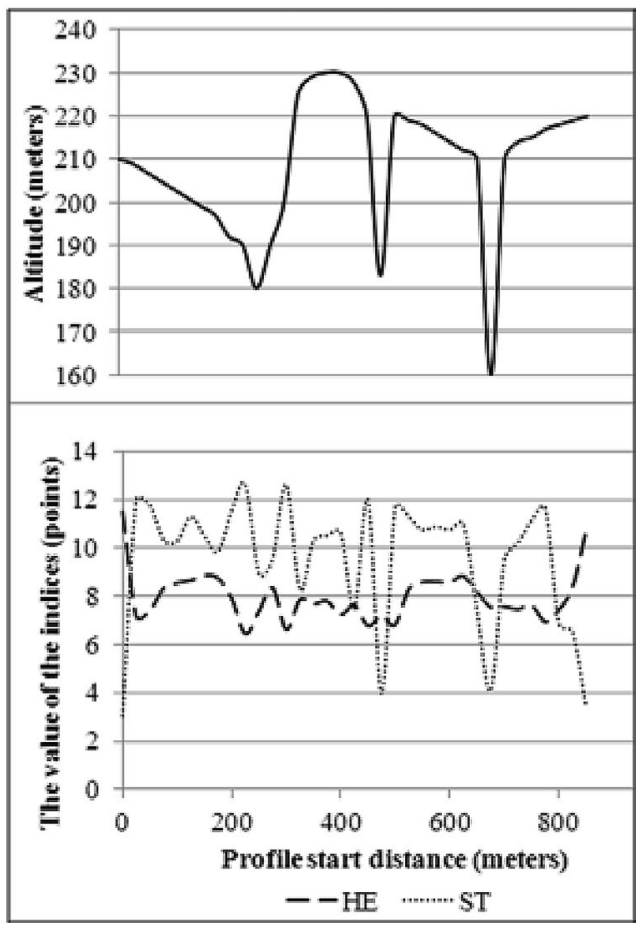

Legend: HE - index of anthropogenic transformation, ST - index of natural dynamics

Figure 10. Change in the value of indices of anthropogenic transformation and natural dynamics on the profile through loess ravines near Zbranky (Source: author's own diagram)

The levels of the anthropogenic transformation changes with the opposite tendency can be observed in the gullies of the Horodetsko-Slovechanske tract which range from 5 to 7 points, and it varies from 5 to 9 points on the Didukh-Khomiak scale in the IlimkivskoKlynetske and Levkovytsko-Korenivske tracts.

Edaphic and dynamic characteristics of landscape ecosystems allow for them to be divided into separate tracts according to the size of the natural dynamics index and anthropogenic transformation index. For the rocky part, the closest ones in terms of these indicators are the Chervonsko-Horodetske and Lystvynsko-Perebrodske tracts. Nowadays, roughly the same anthropogenic pressure is observed here. However, there are historical differences. On the territory of the first tract, due to the presence of significant solid woods of Quercus petraea (Matt.) Liebl., a number of reserves were created in the 1980s. On the territory of the Lystvynsko-Perebrodske tract, a large reserve "Slovechansko-Ovruchsky Ridge" was created only in the late 1990s. Thus, in recent decades, the anthropogenic pressure in both tracts is approximately the same, but in the first, the indicators of natural dynamics are slightly higher (Khomiak et al., 2019). The 
Tkhorynsko-Pishchanitske and Bigunsko-Horodetske tracts differ from the rest by the presence of massive sandy deposits in their northern outskirts. Under such edaphic conditions, the rate of autogenous succession decreases. There is the possibility to observe a high patchiness of landscapes with their dynamics. For the Tkhorynsko-Pishchanitske tract, it is strengthened by the river valleys of the Prypiat basin, which emerge from the northern slopes of the ridge. The valleys of these rivers with their more fertile meadow soils are used as arable land, hayfields, and pastures. This contributes to an increase in the level of anthropogenic transformation in such places up to 8-11 points.

Each of the landscape ecosystems has its own balance between allogeneic (mainly direct and indirect anthropogenic) and autogenous influences. As a result of this, over time the position of the ordination field of the ecosystems is shifted within the edapho-dynamic model. There are three complexly organized processes here: the predominance of autogenous succession, which leads to the formation of forest landscapes with primeval forests; the balance between opposite processes that stops dynamic changes in landscapes; and the predominance of allogeneic processes that leads to the temporary degradation of the vegetation cover (Khomiak, 2014). German researchers obtained similar results for the territory of Germany (Walz and Stein, 2014). They observed changes in the hemeroby index during the expansion of lignite mining and agricultural industrialization (Steinhardt et al., 1999). The vegetation is a good indicator of these processes. This indicator can thus be used to determine the dynamics of landscapes under the influence of natural processes and anthropogenic pressure. Mark Oliver Hill, David Brian Roy and Ken Thompson point to several ways of using plants as indicators of hemerobia (Hill et al., 2002), such as individual characteristics of species, their origin, belonging to a certain class of phytocenoses and others. The authors draw attention to the difficulties of using this approach. Our method of determining hemerobia avoids a number of these problems.

\section{CONCLUSION}

Anthropogenic impact slows down or reverses the processes of natural dynamics in most cases. The dynamic equilibrium is shifting towards pioneer ecosystems under the influence of human activity. Anthropogenically transformed ecosystems of the eastern part of the Slovechansko-Ovruchsky ridge are at the earlier stages of autogenic succession than the natural ecosystems of the western part in similar conditions.

The level of anthropogenic transformation is directly dependent on soil conditions and microrelief for areas located nearby and with the same history of human activity. The level of anthropogenic transformation is higher for the territory where the conditions of agriculture are better. That is why forests are more common in the areas with sodpodzolic soils and agricultural landscapes in the areas with gray forest soils.

Deviation of the moisture level from the optimum for terrestrial ecosystems leads to a decrease of the natural dynamics index in weakly anthropogenic ecosystems (western part of the Slovechansko-Ovruchsky ridge) and to an increase in strongly anthropogenic ecosystems (eastern part of the Slovechansko-Ovruchsky ridge). 
Forest planting slows down or stops autogenic succession if the planted species belong to alien invasive species of transformers. Plantations of these species have displaced natural vegetation and changed the direction of ecosystem dynamics in the east of the Slovechansko-Ovruchsky ridge.

The landscapes and tracts identified by vegetation are well correlated with indicators of environmental factors, the level of anthropogenic transformation and the value of the natural dynamics index.

The information obtained can be used for a strategic planning of the use of natural resources and protection of natural habitats. The western part of the SlovechanskoOvruchsky ridge is most suitable for the creation of a national nature park.

\section{REFERENCES}

Andrienko, T. L., Bilyk, G. I., Bradis, E. M. and Barbarych, A. I. (1977). Geobotanical Zoning of the Ukrainian SSR. Kyiv: Naukova Dumka.

Blume, H. P. and Sukopp, H. (1976). Ökologische Bedeutung anthropogener Bodenveränderungen. Schriftenreihe für Vegetationskunde, 10: 75-89.

Cordingley, J. E., Newton, A. C., Rose, R. J., Clarke, R. T. and Bullock, J. M. (2016). Can Landscape-Scale approaches to Conservation Management Resolve Biodiversity-Ecosystem Service Trade-Offs? Journal of Applied Ecology, 53(1): 96-105.

Didukh, Ya. P. (2005). Theoretical Approaches to Creating a Classification of Ecosystems. Ukrainian Phytosociological Collection, Series C, 23: 3-15.

Didukh, Ya. P. (2008). Sketches of Phytoecology. Kyiv: Aristej.

Didukh, Ya. P. (2012). Basics of Bioindication. Kyiv: Naukova Dumka.

Didukh, Ya. P. and Khomiak, I. V. (2007). Estimation of the Energy Potential of Ecotopes Depending on the Degree of Their Hemerobia on the Example of Slovechansko-Ovruchsky Ridge. Ukrainian Botanical Journal, 64(1): 235-243.

Didukh, Ya. P. and Plyuta, P. H. (1994). The Phytoindication of Ecological Factors. Kyiv: Naukova dumka.

Hill, M. O., Roy, D. B. and Thompson, K. (2002). Hemeroby, Urbanity and Ruderality: Bioindicators of Disturbance and Human Impact. Journal of Applied Ecology, 39(5): 708-720.

Khomiak, I. V. (2006). Features of the Territorial Differentiation of Ecotopes of Forest Formations of the Slovechansko-Ovruchsky Ridge. Ukrainian Botanical Journal, 63(2): 235-243.

Khomiak, I. V. (2014). New Location of Botrychium lunaria (Ophioglossaceae) on the Territory of Central Polissia. Ukrainian Botanical Journal, 71(2): 206-208.

Khomiak, I. V. (2015). Influence of Environmental conditions on the Direction of Primary Successions in the Area of Forest Species Outcrops of the Right-Bank Polissia. Bioindication and Ecology, 20(1): 35-46. 
Khomiak, I. V. and Didukh, Ya. P. (2009). New Find of Cypripedium calceolus L. (Orchidaceae) in Zhytomyr Polissia. Ukrainian Botanical Journal, 66(6): 820-824. Khomiak, I. V. and Onyshchuk, I. P. (2018). Distribution of Polystichum aculeatum (L.) Roth. (Dryopteridaceae) on the Territory of the Slovechansko-Ovruchsky Ridge. Proceedings of NaUKMA. Biology and Ecology, 1: 48-51.

Khomiak, I. V., Bren, A. L., Onyshchuk, I. P., Kotsiuba, I. Yu. and Shkyliuk, Yu. V. (2020). The Review of the Monograph of the Vegetation of Ukraine. Ecological Sciences, 2: 170-173.

Khomiak, I. V., Demchuk, N. S. and Vasylenko, O. M. (2018). Phytoindication of Anthropogenic Transformation of Ecosystems on the Example of the Ukrainian Polissia. Ecological Sciences, 3(22): 113-118.

Khomiak, I. V., Harbar, O. V., Nykonchuk, Ye., Demchuk, N. S. and Harbar, D. A. (2019). Ecological and Cenotic Characteristics of the Population of Hedera helix L. (Araliaceae) on the Territory of the Slovechansko-Ovruchsky ridge. Lesia Ukrainka Eastern European National University Scientific Bulletin Series. Series: Biological Sciences, 3(387): 32-37.

Khomiak, I., Harbar, O., Demchuk, N., Kotsiuba, I. and Onyshchuk, I. (2019). AboveGround Phytomas Dynamics in Autogenic Succession of an Ecosystem. Forestry Ideas, 25(1): 136-146.

Koshik, Yu. A., Timofeev, V. M. and Chmychal, V. N. (1976). Features of the Relief of the Glacial Region of Zhytomyr Polesye. Kyiv: Naukova Dumka.

Margalef, R. (1994). Dynamic Aspects of Diversity. Journal of Vegetation, 5(4): 451-456.

Melnyk, V. I., Baranivsky, O. R., Kharchyshyn, V. T., Kornijchuk, V. S., Titova, O. T. and Khomiak, I. V. (2009). Floristic Finds in Zhytomyr Polissia. Introduction of Plants, 2: 3-8.

Myrkyn, B. M., Naumova, L. H. and Solomeshch, A. I. (2001). Modern Vegetation Science. Moscow: Logos.

Simeonova, V., Bos, E., Jongman, R. and Zingstra, H. (2009). Implementation of Ecological Networks in Different Socio-Economic Contexts: Guiding Principles Based on Experiences in Central and Eastern Europe. Alterra-rapport 1896. Wageningen: Alterra.

Sochava, V. B. (1967). Advances in Thematic Mapping and Vegetation Mapping. Geobotanical Mapping, 3-9.

Sochava, V. B. (1968). Plant Communities and the Dynamics of Natural Systems. Reports of the Institute of Geography of Siberia and the Far East, 20: 12-22.

Steinhardt, U., Herzog, F., Lausch, A., Müller, E. and Lehmann S. (1999). Hemeroby Index for Landscape Monitoring and Evaluation. In: Pykh, Y. A., Hyatt, D. E. and Lenz, R. J. (eds.), Environmental Indices - System Analysis Approach (pp. 237-254). Oxford: EOLSS Publications.

Tutkovsky, P. A. (1923). Slovechansko-Ovruchsky Ridge and the Coast of the River Slovechna. Geological and Geomorphological Description. Kyiv: UAS Publishing House. 
Walz, U. and Stein, C. (2014). Indicators of Hemeroby for the Monitoring of Landscapes in Germany. Journal for Nature Conservation, 22(3): 279-289.

Yakushenko, D. M. (2005). Ecosystems of Zhytomyr Polissya: Classification, Territorial Differentiation, Protection (extended abstract of candidate's doctoral thesis). Kyiv: National Taras Shevchenko University of Kyiv. 


\title{
DINAMIKA ANTROPOGENIH I PRIRODNIH KRAJOBRAZNIH EKOSUSTAVA SLOVEČANSKO-OVRUŠKOG GREBENA U UKRAJINI
}

Oleksandr Harbar, Ivan Khomiak, Iryna Kotsiuba, Natalia Demchuk i Iryna Onyshchuk

\section{Sažetak}

Upravljanje krajobrazima ne može se temeljiti isključivo na statičnim podacima. Krajobrazni ekosustavi složeni su dinamični objekti pa uspješna zaštita i upravljanje takvim područjima ovisi o kvaliteti praćenja njihove dinamike te prognozama koje se na temelju toga oblikuju. Točnost prognoza ovisi i o kvaliteti modeliranja zbog čega je važno odabirati najuniverzalnija i ključna obilježja ekosustava. Zbog toga je Slovečansko-Ovruški greben kojeg obilježava iznimno bogata krajobrazna raznolikost prikladan kao objekt za ispitivanje različitih pristupa modeliranju. Autori su izdvojili 11 teritorijalnih dijelova SlovečanskoOvruškog grebena na razini krajobraza i trakta. Diferencijacija krajobraza procijenjena je metodom sinfitoindikacije kako bi se utvrdila vrijednost njihove prirodne $i$ antropogene dinamike. Zatim su izradeni prognostički algoritmi za promjene u ekosustavima koristeći geobotaničke podatke, što omogućuje oblikovanje prikladnijih strategija zaštite krajobraza te njihova učinkovitijeg i sigurnijeg iskorištavanja.

Ključne riječi: staništa, autogene sukcesije, alogene sukcesije, monitoring okoliša, ljudski utjecaj

\section{DYNAMIK DER ANTHROPOGENEN UND NATÜRLICHEN LANDSCHAFTSÖKOSYSTEME DES SLOVETSCHAN-OVRUSCH- GRATES IN DER UKRAINE}

\author{
Oleksandr Harbar, Ivan Khomiak, Iryna Kotsiuba, Natalia Demchuk und Iryna Onyshchuk
}

\section{Zusammenfassung}

Das Landschaftsmanagement kann nicht ausschließlich auf statistischen Angaben beruhen. Landschaftsökosysteme sind komplexe und dynamische Objekte und ein erfolgreicher Schutz und Verwaltung solcher Gebiete hängt von der Qualität der Überwachung, deren Dynamik und der darauf beruhenden Prognosen ab. Die Richtigkeit der Prognosen hängt von der Qualität der Modellierung ab, deshalb ist es wichtig, die universalsten und wichtigsten Merkmale des Ökosystems auszuwählen. Aus diesem Grund ist der Slovetschan-Ovrusch-Grat mit einer Vielfalt der Landschaften dazu geeignet, den Modellieransatz zu testen. Die Differenziertheit der Landschaften wurde mit Hilfe der Synphytoindikationsmethode geschätzt, damit der Wert der natürlichen und anthropogenen Dynamik festgestellt werden kann. Dann wurden prognostische Algoritmen für Änderungen in den Ökosystemen unter Anwendung von gebotanischen Daten erstellt. Dadurch wird ermöglicht, eine besser geeignete Strategie zum Landschaftsschutz zu bilden und die Landschaft auf eine effizientere und sicherere Art und Weise zu nutzen.

Schlüsselwörter: Habitate, autogene Sukzession, allogene Sukzession, Landschaftsüberwachung, Einfluss des Menschen 